
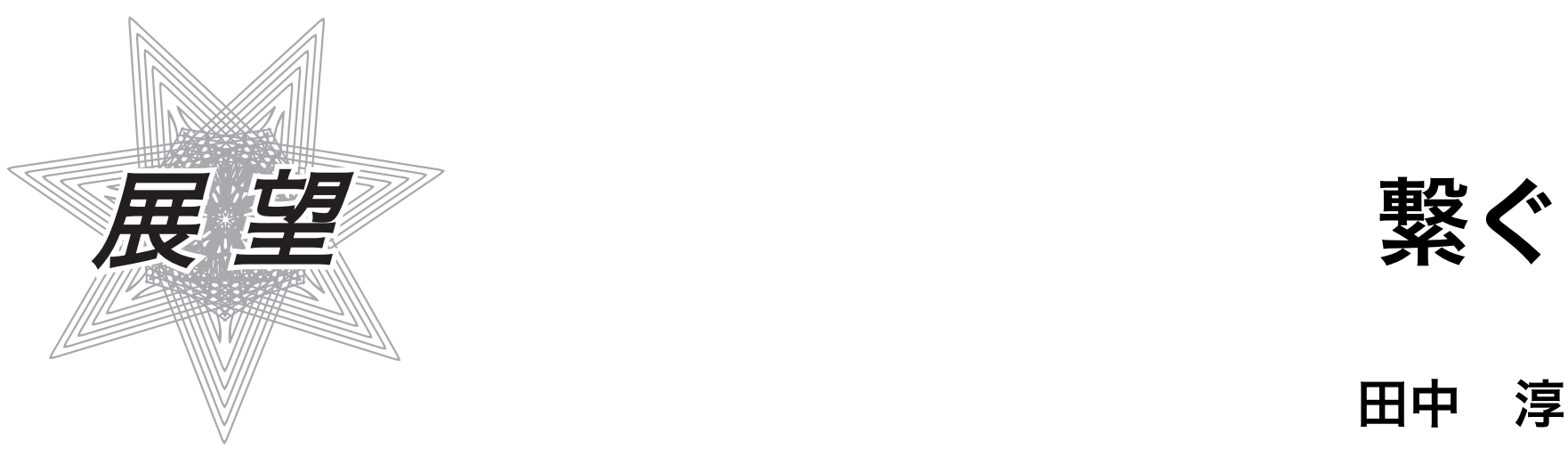

\title{
田中 淳
}

箱根駅伝が面白い. 連覇や捲土重来を胸に秘めた求道者然の選手たちが抜きつ抜かれつ. 観る者をわくわくさせるシ ナリオのないドラマである. 自分の人生を重ねて観ている人も多いに違いない. 受け継ぎ, そして託す。「繋ぐ」. 私事 で恐縮だが，そこからすぐ連想するのは，中学から始めたバスケットである．中学時代，一年先輩たちは非常に優秀で, それまでほぼ無名だったチームが快進撃を続け, 県大会で準優勝。一方, それを引き継いだ我々は, 優勝間違いなしと 信じた地区大会でまさかの敗退. 小生は主将だったこともあり，繋げなかった無念さは今も拭い切れない，生涯消える ことはないであろう。

電気化学会は, 草分けたる東工大の加藤与五郎博士を初代会長に擁し, 80 年余の歴史を繋いできた. また, 電気化学 はSDGs (Sustainable Development Goals) とょく整合しており，社会的要請・注目度はますます高まっている，今，世界 の電気化学のフロンティアに位置する本会は貴重な存在である.

「本会のスローガンは？」と問われれば，旗幟鮮明に一言「魅力ある学会作り」と答えたい。これは前渡邊会長も言 及されてきたことである，以下，「繋ぐ」2点を活動方針として付言したい.

一つは，産学官連携の強化である。

そもそも電気化学は学際・業際的色彩が強い. 再び私事で恐縮だが, 小生はもともと有機化学であった。 入社 9 年後 に，いろいろな契機が重なって無機化学に転じることになった，土地勘の無さから，戸惑いや焦燥は頻繁に生じたが， ある時, 電子の動きが物質変化・機能発現の基本であると気がついた。開き直りだったのかもしれない，そこから連続 性が生まれ，面白いように理解が進しだ記憶がある。電気化学はまさにそこに位置している，そして，日本人はすり合 わせが得意な民族である。従って，本会には連携成果を出せる土壤・機会がふんだんにあるはずである，ただし，学で あれ産であれ，連携を成果・成功に導くのは社会課題解決意識と連携組織トップの本気度・信頼関係であろう。

もう一つは，人材育成と次世代継承の推進である.

「繋ぐ」と言えば必ずこれが話題に上り，そしてそれは常に重い。コミュニケーションはむずかしい. 伝える側・受 け取る側それぞれに固有フィルターがあり，決して100\%は伝わらない。選手の走り, 攻守のパターン，実験のテク ニック，作業マニュアル，こういったものは有形である，ある意味わかりやすく，評価しやすい. しかし，連綿と続い てきた根柢にあるもの, 理念や文化と言われるようなものの伝承は容易ではない.さ らに，それらを消化したのちに，乗り越えるべく，新たな血や文化を導入して止揚の 道を目指すとなれば筆舌に尽くしがたい努力を要する，今多くの組織に求められてい るのはそれであろう。本会も例外ではないと思っている.

研究開発を山に例えれば，その裙野の広大さが姿に威容を与え，頂きに輝きを添え る。また，現在われわれは質の高い生活を当たり前のように享受できているが，それ は先人の数多くの失敗と経験の上に構築された，いわば歴史の上澄みをすくい取って いるのに過ぎない，歴史と理念・社会的意義を振り返りつつ，若い研究開発人材の育 成と継承を推進すること，それが本会発展さらには日本の国力の礎にも深くつながる ことと信じている.

本会には，本会委員会・支部・専門委員会・研究技術懇談会など多くの組織がある が，今後は一丸となって，会員の皆様と一緒に「繋いで」「魅力ある学会」を作って いきたい. 新時代「令和」にて大輪の花を咲かせるべく, 関係各位のご理解とご支援 を切にお願いする次第である.

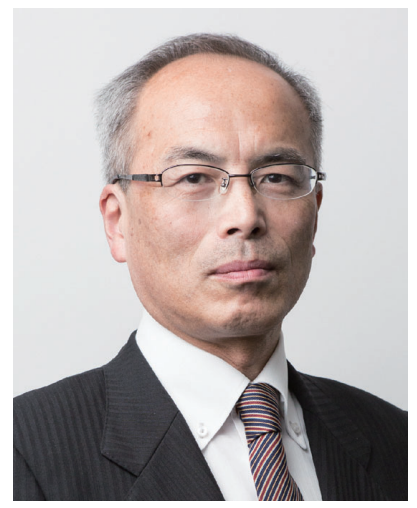

Jun TANAKA 本会 2019 年度会長 昭和電工 (株) 常務執行役員 CTO 